\title{
PEMETAAN MEDIA LOKAL ACEH; KEHADIRAN, TANTANGAN SERTARELASINYA DENGAN POLITIK LOKAL
}

\author{
Nellis Mardhiah \\ Program Studi Ilmu Administrasi Negara \\ Universitas Teuku Umar \\ Email: Nellismardhiah@gmail.com
}

\begin{abstract}
Theoretically, the media and politics can not be separated. Media and politics are like two sides of the same coin in which each one requires another. This is what happened in Aceh. Media and political links are highly visible in the practice of the press in Aceh. The presence of the media in Aceh seems very much to serve the political ambition through the news. The practice of the press industry looks like it is thick with the nuances of interest, which is interestingly studied with the approach of political economy. Political economy theorists see that there are certain groups that control economic institutions that then affect other social institutions, including the media and the press. In other words, the mastery of economic institutions will lead to the mastery of almost all aspects of life, ranging from small things such as how to eat to big things like communication devices. The mastery is meant to perpetuate their economic power. In the context of Aceh specially post-enactment of the Law on Aceh Goverment. The presence of local media is not only a part of the vortex of information, but also present as part of local political democratization. This is the challenge of the media or the local press itself. Does the media capable of maintaining its independence in managing information? or actually engaging in political practices in favor of certain political groups?
\end{abstract}

Keywords: Local Media, Political Economic Media, Elite Politic, Aceh.

\section{PENDAHULUAN}

\section{Latar Belakang Masalah}

Kehadiran suratkabar lokal dapat dijadikan indikator dari dinamika kehidupan lokal. Berbagai kegiatan institusi sosial dalam kehidupan publik akan muncul dalam media lokal. Otomatis warga akan memerlukan media lokal. Masalahnya, apakah dinamika masyarakat lokal sudah bergerak setelah Era Otonomi? Kalau alam pikiran warga masih masih didominasi dengan peristiwaperistiwa di pusat, sementara kehidupan publik pada tingkat lokal belum cukup dinamis dalam otonominya, kehadiran media lokal belum menjadi kebutuhan langsung warga masyarakat.

Dari sini bisa dipahami fungsi utama media pers, yaitu untuk menyediakan informasi bagi person-person yang secara aktual berada dalam berbagai institusi sosial. Sering disebut, media pers hadir sebagai institusi sosial, karenanya dilekati dengan fungsi yang harus dijalankannya dalam kehidupan masyarakat. Keberadaan dalam kehidupan sosial ini menjadikan pengelola media 
sebagai aktor sosial yang harus menjalankan fungsinya sesuai dengan harapan (expectation) dari masyarakat. Harapan inilah yang menjadi pendorong dalam menformat fungsi imperatif yang harus dijalankan oleh media massa sebagai institusi sosial. Ia dapat berupa dorongan psikologis khalayak, tetapi yang tak kalah pentingnya adalah dorongan sosiologis. Jika dorongan pertama membawa seseorang ke dunia dalam (inner world) yang bersifat subyektif, maka dorongan kedua membawa seseorang ke dunia luar yang bersifat empiris obyektif. Media pers akan mensuplai masyarakatnya untuk dapat memasuki dunia yang dipilihnya. Materi informasi fiksional semacam musik akan membawa penggunanya ke dunia subyektif, sedang materi faktual seperti berita (news) digunakan sebagai dasar memasuki dunia sosial empiris.

Pilihan seseorang akan informasi ditentukan oleh posisinya dalam struktursosial. Adapun informasi selamanya memiliki fungsi pragmatis bagi penggunanya. Seseorang yang memiliki peran dalam struktur sosial, secara hipotetis dapat dibayangkan akan lebih memerlukan materi informasi faktual. Karena dengan informasi faktual ini dia menempatkan dirinya dalam interaksi sosial. Sebaliknya, semakin tidak berperan seseorang dalam kehidupan sosial, dengan sendirinya secara relatif dia tidak memerlukan informasi faktual. Ini kiranya dapat menjelaskan mengapa informasi hiburan lebih banyak peminatnya di tengah struktur masyarakat yang bersifat elitis, karena terbatasnya jumlah warga yang memiliki peran sosial. Dengan kata lain, melalui terbatasnya pengguna informasi faktual dapat dijadikan indikator atas terbatasnya peran warga dalam kehidupan publik. Dengan begitu skala lingkup kehidupan sosial dengan peran warga di dalamnya, akan menentukan tipe informasi yang relevan baginya.

Dalam konteks Aceh khusunysa pasca pemberlakuan Undang-Undang Pemerintahan Aceh. Kehadiran media local tidak hanya sebagai bagian dari pusaran informasi, melainkan juga hadir sebagai bagian demokratisasi politik local. Inilah yang menjadi tantangan dari media atau pers local itu sendiri. Apakah media mampu menjaga ke-independensi-annya dalam mengelola informasi atau justru terlibat dalam praktik-praktik politik dalam mementingkan kelompok-kelompok politik tertentu.

Secara teoritis, media dan politik memang tidak bisa dipisahkan. Media dan politik bagaikan dua sisi mata uang yang sama di mana masing-masing elemen satu memerlukan elemen lainnya. Inilah yang terjadi di Aceh. Kaitan media dan politik sangat kentara dalam praktik pers di Aceh. Kehadiran media di Aceh tampak sekali berupaya melayani ambisi politik melalui pemberitaan. Praktik semacam itu persis kesimpulan Ignatius Haryanto (2011) ketika melihat pers lokal setelah sepuluh tahun Reformasi:

"Menjadi suatu praktik umum di mana media massa di berbagai wilayah tak bisa beroperasi sebagai perusahaan yang sehat, tidak profesional, dan menunjukkan ketergantungan yang sangat besar pada dinamika yang terjadi dalam politik lokal (mulai dari langganan koran oleh kantor-kantor pemerintah, iklan ucapan selamat kepada pejabat, hingga berbagai bentuk suap lainnya."

Praktik industri pers seperti itu terlihat kental dengan nuansa kepentingan, yang menarik dikaji dengan pendekatan ekonomi politik. Para teoretikus ekonomi politik melihat bahwa ada kelompok tertentu yang mengendalikan institusi ekonomi yang kemudian memengaruhi institusi sosial lainnya, termasuk media dan pers. Dengan kata lain, penguasaan institusi ekonomi akan berujung pada penguasaan nyaris seluruh aspek kehidupan, mulai hal kecil seperti cara makan hingga hal besar seperti perangkat 
komunikasi. Penguasaan itu dimaksudkan untuk melanggengkan kekuasaan ekonomi mereka.

Meskipun praktik yang kental kepentingan tersebut berlaku umum di dalam industri pers daerah di Indonesia, menurut Haryanto (2011), "tak mudah bagi masyarakat untuk mengetahui" apa yang sesungguhnya terjadi di sebaliknya. Tentu saja para peneliti dan sarjana yang mesti melihat fenomena tersebut lebih jauh. Sayangnya, tidak banyak peneliti yang melakukannya. Kenyataannya ada rangkap kekosongan akademis di sini. Pertama, kajian terhadap pers lokal sendiri bisa disebut minim. Haryanto (2011) menyebutnya sebagai "tidak ada data". Penelitian kebanyakan dilakukan terhadap "pers nasional" (Hill \& Sen, 2007), yang tentu saja ironis di tengah fenomena merebaknya industri pers lokal atau pers daerah (Robinson, 2008)

Kedua, telaah ekonomi politik untuk mengudar berbagai kepentingan yang berjalinkelindan di balik sebuah kebijakan cukup lama absen dalam dunia akademik di Indonesia. Penyebabnya, menurut Vedy R. Hadiz, kekuasaan Orde Baru selama lebihkurang 32 tahun melarang analisis-analisis kapitalisme dan kelas dengan pisau bedah Marxisme, padahal analisis terakhir ini merupakan basis dalam teori ekonomi politik. Analisis apa pun, ketika menggunakan pendekatan tersebut, dengan segera dianggap sebagai Kiri oleh Orde Baru. Ironisnya, saat itu kekuatan kapital sedang tumbuh di Indonesia (Robinson, 2008) yang segera memicu para sarjana Indonesia melakukan analisis terhadapnya. Walhasil, dengan sedikit pengecualian, yang muncul kemudian adalah analisis-analisis yang disebut Hadiz (2002) sebagai "most banal forms and narrow behaviorism".

Berdasarkan latar belakang di atas, maka penelitian ini ingin menjawab bagaimana peta/lanskap media lokal di Aceh yang meliputi kehadiran, tantangan serta relasinya dengan politik local di Aceh? Penelitian ini menggunakan data kualitatif sebagai data primer dan serta tidak menutup kemungkinan data sekunder juga digunakan dalam penelitian ini. Selain itu penelitian ini berupaya melihat pemetaan media lokal di Aceh pasca-Orde Baru, dinamika ekonomi-politik yang menyertainya, serta sistem pers yang tumbuh di Aceh. Argumen yang mendasarinya adalah bahwa konteks pasca-Orde Baru serta MoU Helsinksi menyediakan kesempatan yang lebih luas bagi perkembangan industri pers lokal, seiring dengan tumbuh dan masuknya kapital ke daerah serta munculnya aktor- aktor politik lokal pasca-desentralisasi. Karena itu, analisis ekonomi politik menjadi penting digunakan sebagai pisau analisis dalam penelitian ini, yang hasilnya akan digunakan untuk melihat sistem pers yang tumbuh di Aceh.

\section{KAJIAN LITERATUR}

\section{Media Lokal: Berperan Positif atau Negatif?}

Menyebut dan mendefinisikan media lokal di masa sekarang sebetulnya problematis. Di dalam Understanding the Local Media, Meryl Alridge (2007) menyebut problem tersebut terutama terkait realitas dunia saat ini yang semakin mengglobal, ditandai dengan temuan-temuan teknologi modern yang mengatasi hambatan jarak yang sebelumnya menjadi pemisah. Globalisasi yang memungkinkan interaksi sosial antarwarga dunia secara real-time, yang semakin menyempurnakan gagasan global village dari Marshall McLuhan, pada gilirannya mengubah kebudayaan manusia untuk tidak hanya berpikir tapi juga bertindak secara global. Dan media, sebagai sarana komunikasi massa, demikian Alridge, merupakan pemain paling penting yang mendorong terjadinya globalisasi (2007; Hal 7-8) Dengan sifat dasarnya yang global, bagaimana mungkin kemudian ada yang dinamakan media lokal? 
Rupanya, menurut Alridge, di tengah gelombang globalisasi, kerinduan pada lokalitas juga menguat. Di samping dipengaruhi oleh berbagai faktor global, apa yang disebut kenyataan hari ini tidak bisa tidak dibentuk oleh lokalitas yang dekat (immediate locality). Dalam definisi globalisasi, misalnya yang dikemukakan Giddens, ditekankan pentingnya keterlibatan lokal (local involvement) dalam pembentukan sebuah kejadian, di samping tentu saja interaksi lintas jarak (interaction across distance) yang merupakan sumbangan global. Kerinduan akan lokalitas itu, menurut Alridge, menyebabkan preferensi masyarakat Inggris, negara yang dia teliti, terhadap media yang mengangkat berita lokal sangat kuat (Ashadi, 2002).

Pemberitaan atau orientasi lokal, dalam pandangan Ashadi Siregar, merupakan salah satu ukuran untuk melihat apakah sebuah media bisa disebut media lokal atau tidak, di samping sirkulasi. Siregar membuat tiga "tingkatan" media berdasarkan orientasi dan sirkulasi tersebut, yang merupakan "tingkatan" keduanya: lokal, regional, dan nasional. Menurut Siregar, "nasional melingkupi seluruh wilayah negara; regional mencakup sebagian wilayah nasional, bersifat antar daerah; sedang lokal mencakup satu kota atau daerah terbatas." Dengan kerangka seperti itu, terbuka kemungkinan sebuah media misalnya berorientasi lokal namun diedarkan secara nasional atau sebaliknya berorientasi regional tapi sirkulasinya hanya lokal. Apa yang disebut media lokal, dalam pandangan Siregar, sejatinya adalah yang berorientasi lokal dan wilayah sirkulasinya juga lokal.

Definisi Siregar tentulah terasa amat longgar jika dibandingkan definisi dari Bob Franklin (2006) yang mensyaratkan media lokal "dimiliki orang lokal, diproduksi secara lokal, mempekerjakan jurnalis lokal, melaporkan apa yang menjadi konsen lokal, dan dibaca oleh penduduk lokal." Kalau Siregar hanya menekankan orientasi pemberitaan dan wilayah edar, Franklin menambahkan pemilik, produksi, dan pekerja media mesti juga bersifat lokal. Meskipun membuat definisi ketat, Franklin pesimis semua syarat lokal itu bisa dipenuhi. Franklin sendiri menyebutkan, di masa sekarang, apa yang disebut media lokal tinggal nama semata. Pemilik media lokal kerap kali adalah kelompok jaringan media yang tidak hanya memiliki media di suatu daerah tetapi juga di daerah lain, bahkan bisa jadi kelompok industri dari negara lain. Dengan kepemilikan yang demikian, produksi bisa berada di tempat yang jauh serta keputusan redaksional ditentukan dari wilayah lain. Hal yang paling mengkhawatirkan, sebagai konsekuensinya, adalah terputusnya relasi antara masyarakat suatu wilayah dan media yang beredar di sana. Sama halnya dengan pendapat Franklin, relasi kedua hal itu juga sangat penting bagi Siregar. Keduanyalah yang disebut Siregar sebagai orientasi dan sirkulasi, yang sesungguhnya menunjukkan dua fungsi atau peran media: sebagai institusi sosial dan institusi bisnis. Kata Siregar,

Sebagai institusi sosial, [media] berorientasi ke luar (outward looking) untuk kepentingan masyarakat. Sebagai institusi bisnis, media massa sama halnya dengan setiap korporasi, yaitu menjalankan operasinya dengan orientasi ke dalam (inward looking), untuk kepentingan sendiri.

Dua peran tersebut dalam kenyataannya sulit seiring sejalan dan kerap menjadi dilema dalam kerja-kerja jurnalistik, termasuk bagi media lokal. Dalam konteks Indonesia, perkembangan jumlah media lokal yang luar biasa pasca-Reformasi (Sutrisno, 2009) tidak hanya disebabkan oleh penghapusan SIUP sebagai syarat penerbitan media, melainkan juga buah dari dinamika lokal seiring kebijakan desentralisasi. Perubahan lanskap politik Indonesia yang menjadikan kabupaten dan kota sebagai basis otonomi pada gilirannya membutuhkan ruang publik bersama yang berfungsi menghasilkan imajinasi komunitas dan identitas yang dicita-citakan. Dalam sejarah Indonesia modern, media dianggap mampu memenuhi tugas tersebut (Anderson, 2009) Walhasil, meskipun 
merupakan institusi bisnis, media lokal sejatinya tidak melupakan tugasnya sebagai institusi sosial. Dua peran tersebut seyogianya berjalan beriringan. Pertanyaannya, apakah media lokal telah melaksanakan kedua tugas tersebut?

Walaupun media lokal tumbuh subur pasca-Orde Baru, anehnya, penelitian tentangnya tidak banyak dilakukan. Dalam refleksinya setelah satu dasawarsa Reformasi, Haryanto (2011) menyebut "tidak ada data" tentang media lokal. Haryanto jelas berlebihan dengan kesimpulan itu, karena kenyataannya, meskipun bisa dibilang sedikit, beberapa riset tentang media lokal telah dilakukan. Secara umum, riset-riset tersebut dapat dikelompokkan menjadi dua: peran media lokal dinilai positif dan sebaliknya perannya dianggap negatif.

Penelitian Tessa Piper (2009) misalnya melihat peran yang dimainkan media bersifat positif, yakni memperkuat peran masyarakat sipil dalam melakukan pengawasan pemerintahan lokal dan menjalankan kerja-kerja pemberdayaan. Media lokal juga membiakkan kembali akan harapan tumbuhnya komunikasi yang demokratis di dalam masyarakat.

Sementara itu, penelitian Eriyanto (2008), David T. Hill (2011), dan Birgit Brauchler (2011) memandang peran media lokal sebagai negatif. Media-media lokal tersebut memperkeruh konflik, bukan mendamaikan, serta berlaku klientelis dalam ajang kontestasi politik lokal. Peran negatif itu diambil media dengan tujuan mengambil laba atau keuntungan sebanyak mungkin untuk membesarkan institusinya. Mereka membuktikan perkembangan industri media lokal pasca-Orde Baru ditunjang oleh perilaku media yang tidak semestinya, yang di situ bertemu banyak sekali kepentingan. Industri media lokal di suatu daerah, dengan demikian, butuh telaah yang bukan sekadar ekonomi yang konvensional, melainkan analisis yang mampu melihat celah di antara berbagai kepentingan itu.

\section{Ekonomi Politik dan Persebaran Kapital}

Salah satu analisis yang mengulik berbagai kepentingan di balik sebuah fakta sosial atau peristiwa adalah ekonomi politik. Pada awalnya, analisis ini merupakan kritik terhadap analisis ekonomi konvensional yang menekankan keseimbangan (equilibrium). Adam Smith, pencetus teori ekonomi klasik tersebut, berpendapat bahwa kepemilikan uang atau modal akan menyebar dengan sendirinya melalui mekanisme yang murni pasar berdasarkan prinsip pertukaran (exchange). Dengan prinsip ini, menggenggam semua uang dan melepas seluruh barang hanya akan membuat harga jatuh, sebaliknya mengambil semua barang dan melepas uang akan membuatnya naik. Kedua sudut ekstrem itu tidak mungkin terjadi dan uang akan dengan sendirinya menyebar, yang pada akhirnya membuat keseimbangan antara kepemilikan uang dan barang. Salah satu kritik terhadap ekonomi klasik ini adalah pengabaiannya terhadap berbagai faktor di luar ekonomi seperti struktur sosial, akses informasi, dan lain-lain. Dengan kata lain, ekonomi tidak mempertimbangkan relasi kuasa yang hendak mengontrol pasar dan produksi sekaligus. Sebagai kritik terhadap ekonomi konvensional, karena itu, ekonomi politik didefinisikan sebagai "relasi sosial, khususnya relasi kuasa, yang membentuk produksi, distribusi, dan konsumsi sumber daya" (Mosco, 2009). Komunikasi tentu saja tidak berbeda dari dan termasuk sumber daya tersebut, sehingga produk komunikasi seperti koran dan distribusinya serta pilihan konsumen atasnya juga dibentuk dan dipengaruhi oleh relasi kuasa. Dengan tekanannya pada relasi kuasa, ekonomi politik banyak disumbang oleh tradisi Marxis.

Menurut Vincent Mosco (2009), ada empat karakteristik analisis ekonomi politik, yakni historis, multidisiplin, penekanan pada moral, dan praksis. Penjelasan singkat atas 
keempatnya adalah bahwa berbagai kekuatan yang membentuk sebuah fakta sosial tidak begitu saja bisa dipahami dalam suatu babakan waktu tertentu, karena itu perlu dilihat dalam rentang perjalanan sejarah yang panjang. Demikian pula, suatu fakta sosial itu tidak cukup hanya dilihat dari suatu sudut atau teori saja, melainkan perlu penggunaan banyak teori. Asumsinya adalah sebuah fakta sosial itu kompleks dan total. Berbeda dari analisis lain yang "normal"-nya hanya untuk kepentingan ilmu, ekonomi politik focus pada relasi sosial yang timpang yang merugikan publik, yang hasilnya tidak sekadar refleksi, tetapi praktis dan dapat digunakan atau berguna bagi publik.

Dengan karakteristiknya yang historis dan multidisiplin, pendekatan dalam ekonomi politik menjadi sangat luas. Mosco (2009) sendiri menyarankan tiga pintu masuk, yaitu komodifikasi, spasialisasi, dan strukturasi. Pada intinya ketiganya melihat relasi kuasa yang membentuk perubahan nilai dan fungsi sumber daya (komodifikasi), memengaruhi dinamika ruang di mana sumber daya berada (spasialisasi), dan mengatur praktik sosial dari sebuah sumber daya (strukturasi).

Di Indonesia, analisis ekonomi politik tidak banyak berkembang terutama pada masa Orde Baru. Penyebabnya, menurut Vedi R. Hadiz, politik Orde Baru yang selalu gusar dengan wacana Kiri dan menganggapnya sebagai ancaman. Berikut kegundahan Hadiz (2013) atas kebijakan tersebut dan harapannya setelah Orde Baru runtuh:

"Ketiadaan studi ekonomi politik Indonesia yang serius oleh orang Indonesia, menurut saya, dikarenakan politik marjinalisasi Orde Baru terhadap analisis Marxis. Walaupun tidak semua studi ekonomi politik diinspirasi Marxis - beberapa malah anti-Marxis - tema kembar kapitalisme dan kelas umumnya dianggap milik wacana Kiri. Karena itu, dengan sedikit pengecualian, orang Indonesia menjadi jarang bersentuhan dengan isu-isu terkait kebangkitan kapitalisme di Indonesia. Analisis terhadap politik dan masyarakat Indonesia kemudian cenderung ke bentuk behaviorisme sempit yang sangat dangkal. Kejatuhan Orde Baru dan keterbukaan ruang politik yang dihasilkannya semoga saja melahirkan studi baru ekonomi politik Indonesia oleh orang Indonesia. (Hadiz, dalam "Studies in the Political Economy"; 2013)"

Meskipun bukan yang pertama, sebuah karya yang memberi pengaruh sangat besar dalam kajian ekonomi politik di Indonesia, bahkan juga di Asia Tenggara, adalah Indonesia: The Rise of Capital karangan sarjana Australia Richard Robison, yang terbit perdana pada 1986. Hadiz memujinya sebagai "perintis jalan yang secara signifikan mengubah fokus kajian Asia Tenggara dan Indonesia pada 1980-an dari pendekatan tingkah-laku (behaviourism), sistem dunia (world system), dan ketergantungan (dependencia theory) menuju 'pendekatan' ekonomi-politik." Buku ini pada intinya membahas pembentukan kelas kapitalis baru Indonesia bersamaan dengan membaiknya perekonomian setelah jalan panjang masa penjajahan, Orde Lama, dan Orde Baru. Penguasa kapital itu, menurut Robison, bukanlah borjuis Muslim tradisional yang pernah berpengaruh pada awal abad ke-20, melainkan para pengusaha Tionghoa dan kaum pribumi yang memegang kekuasaan birokrasi dan berhubungan dengan konglomerat.

Salah satu karya yang dipengaruhi oleh buku Robison adalah disertasi Daniel Dhakidae (1991) di Universitas Cornell. Judul disertasi tersebut secara terang mengambil frasa dari Robison: "The State, the Rise of Capital, and the Fall of Political Journalism: Political Economy of Indonesian News Industry". Disertasi ini menunjukkan bahwa kebangkitan ekonomi Orde Baru dan campur tangan negara terhadap pers membuat industri media bermetamorfosis dari pers politik atau pers perjuangan ke pers Pancasila atau pembangunan. Pers terakhir ini menghilangkan karakter media pada masa Orde 
Lama sebagai alat kompetisi politik menjadi media sebagai institusi bisnis untuk meningkatkan kapital.

Setelah perubahan sangat penting dalam lanskap politik berupa jatuhnya Orde Baru dan masuknya Indonesia ke dalam era baru Reformasi, apa yang terjadi dengan kelas kapital? Bersama sang murid, Vedi R. Hadiz, Robison (2011) menunjukkan bahwa tidak banyak perubahan terkait mereka. Meskipun rezim berganti, struktur kekuasaan dan pengaruh kelas tidak berubah. Birokrat politik dan pengusaha mereorganisasi dan mengonsolidasi kekuasaan untuk kemudian menegaskan diri sebagai sang oligarch.

Meskipun juga melihat adanya kesinambungan kapital di masa Orde Baru dan Reformasi, Edward Aspinall berpandangan bahwa terdapat beberapa perbedaan dan perubahan yang cukup mencolok. Dengan pengusaha Tionghoa tetap menjadi penguasa kapital yang sangat penting, yang berubah sekarang antara lain menguatnya modal swasta dan pribumi yang merupakan buah dari kebijakan proteksionis Orde Baru terhadap keluarga birokrat. Selain itu, perubahan sangat mencolok berkenaan dengan era desentralisasi yang menjadi fokus penelitian ini adalah munculnya pebisnis lokal serta terdistribusinya modal ke daerah-daerah. Hal terakhir ini, menurut Aspinall, memunculkan efek yang kurang menyenangkan dari otonomi daerah: para pengusaha lokal berlomba menjadi bupati atau gubernur atau anggota legislatif, yang selanjutnya melakukan kontrol atas anggaran, serta pada gilirannya saling berkolusi untuk memupuk kekayaan. Praktik korupsi di daerah, demikian Aspinall, tidak pernah sekasat mata di era Reformasi, yang melibatkan utamanya penguasa dan birokrat yang sekaligus juga pengusaha.

Bersamaan munculnya kelas kapital lokal dan terdistribusinya modal ke daerah itulah industri media lokal tumbuh pasca-Orde Baru. Kecuali oleh pengusaha lokal, industri pers di Jakarta dan Jawa kemudian membikin media-media lokal sebagai anak usaha. Di tengah iklim korupsi yang kuat di daerah, media lokal menghidupi dirinya baik sebagai institusi sosial maupun bisnis, yang pada gilirannya membentuk apa yang disebut sistem media.

\section{Sistem Media}

Ada beberapa cara yang digunakan para peneliti untuk melihat kenyataan dan sistem pers di sebuah negara. Fred S. Siebert, Theodore Peterson, dan Wilbur Schramm di dalam buku mereka yang telah menjadi klasik, Four Theories of the Press: The Authoritarian, Libertarian, Social Responsibility, and Soviet Communist Concepts of What the Press Should Be and Do (1963), menganjurkan untuk mengkaji pandangandunia (worldview, welltanschauung) yang dianut warga negara itu. Mereka berpendapat bahwa pandangan- dunia tersebut akan memengaruhi dan pada gilirannya tecermin di dalam media. Mereka mengatakan,

"Untuk melihat sistem sosial dalam hakikat hubungannya dengan pers, seseorang harus mengulik nilai-nilai dasar dan asumsi menyangkut masyarakat dan negara, relasi-relasi negara, serta pengetahuan dan kepercayaan dasariah."

Pendapat Siebert, Peterson, dan Schramm tersebut telah banyak dikritik terutama karena terlalu normatif dan ahistoris (Blumler, 1992), bias Barat terutama ketika menggambarkan pers Uni Soviet (Simpson, 1994), serta kunonya teori tersebut sehingga tidak relevan lagi digunakan setelah Uni Soviet runtuh pada 1980-an (Picard, 1985). Yang sangat mendasar dari banyak kritik itu sesungguhnya mempersoalkan teori mereka 
yang sangat deduktif: bila sistem yang dianut negara adalah A, maka sistem pers yang ada di negara itu juga A. Model penalaran silogis yang ada dalam pendapat Siebert, oleh para pengkritiknya, dianggap mengabaikan kenyataan atau fakta yang kerap berbeda dengan sistem besar negara.

Achmad Zaini Abar (1995), salah seorang pengkritik empat teori pers ala Siebert, Peterson, dan Schramm, menyatakan bahwa kenyataan yang berbeda tersebut sering terjadi terutama di negara dunia ketiga. Di dalam bukunya, Kisah Pers Indonesia: 19661974, Abar menunjukkan bahwa di Indonesia, yang merupakan negara dunia ketiga, pers jauh dari apa yang dicita-citakan oleh demokrasi Pancasila, sistem yang digadang-gadang oleh Orde Baru. Di bawah Orde Baru, pers Indonesia adalah pers yang terkungkung dalam hegemoni dan ketakutan sebab sewaktu-waktu pembredelan bisa terjadi bila pemberitaannya tak memeroleh restu rezim.

Setidaknya ada dua kelemahan dalam kritik Abar terhadap Siebert dkk. Pertama, persoalan sebenarnya bukanlah apa yang dibilang oleh Abar sebagai inkonsistensi sistem dan kenyataan, melainkan bahwa demokrasi Pancasila benar-benar dijadikan sebagai sistem oleh Orde Baru juga masih bisa diperdebatkan. Belakangan lebih banyak yang menyebut sistem pemerintahan Orde Baru adalah otoritarianisme. Walhasil, bila pendapat terakhir ini dipegangi, sistem pers di bawah Orde Baru sesungguhnya sesuai dengan sistem yang dianut negara. Di sini inkonsistensi yang merupakan titik kritik Abar untuk Siebert dkk dengan sendirinya tidak tepat dan malah menguatkan pendapat mereka.

Kedua, pendapat Abar bahwa inkonsistensi sistem negara-sistem pers terjadi di negara dunia ketiga jelas sangat bias Barat. Di dalam ilmu sosial cara pandang ini disebut orientalisme: melihat timur atau dunia ketiga sebagai jelek dan barat sebagai maju dan berperadaban. Cara pandang yang digunakan Abar ini mengabaikan banyak fakta inkonsistensi yang juga terjadi di negara maju. Di Italia di masa kepemimpinan Perdana Menteri Silvio Berlusconi, misalnya, pers dimiliki dan digunakan oleh penguasa untuk kepentingan politiknya. Fakta bahwa sistem pers yang dianut negara-negara maju tidak sama, meskipun mereka mengklaim diri sebagai penganut demokrasi, dengan sendirinya menunjukkan bahwa di sana juga terjadi ketidaksamaan sistem negara dan pers. Paling tidak itu memperlihatkan bahwa sistem pers di negara maju tidaklah monolitik dan tidak mengikut saja, untuk mengatakan sesuai dengan, sistem yang dianut negara.

Meskipun kritiknya mengandung kelemahan, usulan Abar terkait pendekatan untuk melihat sistem pers di suatu negara menarik disimak lebih lanjut. Abar menyebut pendekatan usulannya sebagai pendekatan struktural. Pendekatan yang dipinjam dalam analisis-analisis ilmu sosial, yang mulai marak pada 1970-an, itu berupaya melihat lebih jauh dinamika hubungan pers dengan berbagai kekuatan sosial, ekonomi, dan politik. Meskipun menjelaskan panjang-lebar soal pendekatan struktural yang diusulkannya, Abar abai menunjukkan variabel yang meyakinkan yang dia gunakan dalam melihat sistem pers Indonesia. Bukunya kemudian nyaris bercerita lepas terkait sejarah pers di paruh awal Orde Baru.

Pada titik itu, apa yang ditulis Daniel C. Hallin dan Paolo Mancini (2004) melengkapi pendekatan yang dimaksud Abar. Sama dengan Abar, Hallin dan Mancini juga mengkritik empat teori pers yang mereka sebut sebagai normatif. Sebagai gantinya, mereka mengusulkan pendekatan yang lebih historis, dengan tujuan-tujuan yang dijelaskan sebagai berikut:

"Kami di sini bukan ingin untuk mengukur sistem-sistem media melawan
yang ideal dan normatif, tapi hendak menganalisis perkembangan
historisnya sebagai institusi dalam konteks sosial tertentu. Kami ingin
memahami mengapa sistem- sistem itu berkembang dalam cara yang unik;
apa peran yang mereka mainkan dalam kehidupan politik, sosial, dan 
ekonomi; dan pola-pola relasi mereka dengan institusi sosial lainnya. Model jurnalisme kami merupakan model yang empiris, bukan normatif."

Berbeda dengan Abar, Hallin dan Mancini menjelaskan variabel yang digunakan untuk melihat sistem pers tersebut, yang seluruhnya ada empat variabel. Pertama, industri pers, yang ditekankan pada kuat atau lemahnya sirkulasi media. Kedua, paralelisme politik, yaitu hubungan media dengan kekuatan-kekuatan politik yang ada di masyarakat; sistem media merefleksikan kekuatan politik. Ketiga, profesionalisme jurnalis. Keempat, intervensi pemerintah terhadap pers.

Meskipun yang ditekankan Hallin dan Mancini dengan menggunakan empat variabel tersebut adalah perbandingan sistem pers di beberapa negara, pendekatan yang digunakannya jelas sekali memadai dipakai untuk melihat sistem pers di sebuah wilayah. Bahkan dengan menggunakannya untuk membandingkan sistem pers di banyak negara, pendekatan Hallin dan Mancini berarti telah dipakai dan memadai untuk melihat pers di wilayah-wilayah yang berbeda. Alasan inilah yang membuat penelitian ini memilih pendekatan Hallin dan Mancini. Memang ada kritik bahwa pendekatan mereka terlalu mempertimbangkan faktor politik, sebagaimana anak judul buku mereka, three models media and politics, namun, sebagaimana kasus Aceh yang akan diulas di bawah, kaitan keduanya sangatlah erat.

Tinggal persoalannya, kalau Halllin dan Mancini melihat pers dalam konteks politik negara, apakah bisa pendekatannya dipakai untuk melihat pers di sebuah provinsi di suatu negara? Apakah tidak cukup melihat sistem pers di tingkat negara lalu kemudian menderivasinya ke dalam sistem pers di daerah?

Pasca-Reformasi, Indonesia menerapkan kebijakan otonomi daerah secara berlebihan di Indonesia. Banyak hal yang sebelumnya diatur oleh dan menjadi kewenangan pemerintah pusat, kemudian didelegasikan dan menjadi hak daerah. Kebijakan desentralisasi ini, dalam pandangan banyak pengamat, mengubah secara total landscape politik Indonesia. Aktor-aktor politik lokal bermunculan d(eng)an memanfaatkan sumber-sumber daya yang dimiliki daerah, termasuk sumber daya media. Media di daerah kemudian banyak digunakan untuk melayani kepentingan elite-elite lokal tersebut. Meskipun urusan tentang regulasi media masih berada di pusat, kenyataan media di pusat atau daerah bisa berbeda sama sekali. Ini alasan pentingnya melihat pers di daerah di Indonesia terutama pasca-Reformasi.

\section{HASIL DAN PEMBAHASAN}

\section{Demokrasi dan Konstruksi Sosial dalam Media}

Pandangan penulis menilai posisi media massa memegang peranan yang sangat penting dalam menjalankan sistem demokrasi. Bahkan jurnalisme juga dianggap sebagai pilar demokrasi. Media dan demokrasi merupakan hubungan yang tidak dapat terpisahkan. Keduanya telah melewati sejarah yang panjang dan saling berkesinambungan satu sama lain sejak zaman feodal hingga saat ini. Media massa tanpa adanya demokrasi akan mengalami kemandegan, karena media massa dapat bersuara manakala difasilitasi oleh sistem demokrasi. Begitu juga sebaliknya, demokrasi akan terlihat sinarnya manakala difasilitasi oleh media massa.

Demokrasi baru dapat dikatakan berhasil ketika masyarakat well informed dalam memberikan aspirasi politiknya. Artinya, masyarakat harus memiliki informasi yang cukup dalam menentukan keputusan politiknya dan bukan hanya asal pilih. Disinilah peran media massa untuk memberikan informasi kepada masyarakat untuk membantu mereka 
menentukan pilihannya. Media massa bertanggung jawab memberikan informasi tentang para kandidat dari sisi yang paling objektif sehingga akan menyehatkan persaingan politik di pemerintahan.

Seperti halnya Edmund Burke menyebut media massa sebagai pilar keempat demokrasi. Karena itu, media massa bertanggung jawab sebagai pengawas dan pengontrol para pemegang kekuasaan seperti pemerintah, para pemilik modal, dan institusi-institusi lain yang sekiranya berpotensi mempengaruhi masyarakat. Fungsi media massa tersebut seharusnya juga dapat meningkatkan kewaspadaan institusi-institusi tersebut dalam melakukan aktivitasnya, karena apa yang dilihat media juga akan dilihat masyarakat.

Pendapat lainnya tentang media oleh Karin Wahl Jurgenson dalam Handbook of Journalism Studiesmenulis, secara ringkas media massa, cetak, elektornik atau jurnalisme dalam demokrasi memiliki tiga peran, yaitu (1) jurnalisme sebagai sumber informasi, (2) jurnalisme sebagai watchdog dan pilar keempat demokrasi, (3) jurnalisme sebagai mediator, (4) jurnalisme sebagai advokat. Keempat peran jurnalisme tersebut merupakan tanggung jawab para pengelola media yang harus dipenuhi dalam sistem pemerintahan demokrasi Dahl (1998) dalam Katrin Voltmer, mengatakan munculnya justifikasi normatif terhadap media. Pertama, adanya kebebasan pers (free pers) yang menyediakan ruang debat publik dan bebas bersuara. Hadirnya 'market place of ideas' dimana banyak ide/gagasan yang muncul. Media menjadi sebuah forum dimana berbagai macam kelompok bisa mengekspresikan pendapatnya. Sehingga, bisa disebut bahwa media menghadirkan ruang publik (public sphere) yang akan mendorong terciptanya civil society. Tetapi, disisi lain ada pendapat yang bertentangan mengenai hal ini, bahwa banyaknya opini/sudut pandang yang berbeda malah membuat perselisihan di masyarakat. Masyarakat yang menjadi audiens politik tanpa disertai dalam memilih informasi yang disampaikan, hanya akan membuat suatu hal yang cacat.

Membahas konstruksi sosial (social construction), tidak lepas dari apa yang telah dikemukakan oleh Peter L Berger dan Thomas Luckmann, dalam buku mereka berjudul “the Social Construction of Reality: A Treatisein the Sociology of Knowledge'. Berger dan Luckmann meyakini secara substantif bahwa realitas merupakan hasil ciptaan manusia kreatif melalui kekuatan konstruksi sosial terhadap dunia sosial di sekelilingnya, "reality is socially constructed".

Konstruksi sosial berakar pada paradigma konstruktivis yang melihat realitas sosial sebagai konstruksi sosial yang diciptakan oleh individu yang merupakan manusia bebas. Individu menjadi penentu dalam dunia sosial yang dikonstruksi berdasarkan kehendaknya. Manusia dalam banyak hal memiliki kebebasan untuk bertindak di luar batas kontrol struktur dan pranata sosialnya dimana individu melalui respon-respons terhadap stimulus dalam dunia kognitifnya. Dalam proses sosial, individu manusia dipandang sebagai pencipta realitas sosial yang relatif bebas di dalam dunia sosialnya. Namun demikian, kebenaran suatu realitas sosial bersifat nisbi, yang berlaku sesuai konteks spesifik yang dinilai relevan oleh pelaku sosial.

Pada proses konstruksi jika dilihat dari perspektif Berger dan Luckman berlangsung melalui interaksi sosial yang dialektis dari tiga bentuk realitas, yakni :

a. Objective reality, merupakan suatu kompleksitas definisi realitas (termasuk ideologi dan keyakinan ) serta rutinitas tindakan dan tingkah laku yang telah mapan terpola, yang kesemuanya dihayati oleh individu secara umum sebagai fakta.

b. Symblolic reality, merupakan semua ekspresi simbolik dari apa yang dihayati sebagai "objective reality" misalnya teks produk industri media, seperti berita di media cetak atau elektronika, begitu pun yang ada di film-film. 
c. Subjective reality, merupakan konstruksi definisi realitas yang dimiliki individu dan dikonstruksi melalui proses internalisasi. Realitas subjektif yang dimiliki masing-masing individu merupakan basis untuk melibatkan diri dalam proses eksternalisasi, atau proses interaksi sosial dengan individu lain dalam sebuah struktur sosial. Melalui proses eksternalisasi itulah individu secara kolektif berpotensi melakukan objektivikasi, memunculkan sebuah konstruksi objective reality yang baru.

Selain itu juga berlangsung dalam suatu proses dengan tiga momen simultan, dalam konsep untuk menghubungkan antara yang subjektif dan objektif melalui konsep dialektika, yaitu :

a. Eksternalisasi ialah penyesuaian diri dengan dunia sosio-kultural sebagai produk manusia. "Society is a human product".

b. Objektivasi ialah interaksi sosial dalam dunia intersubjektif yang dilembagakan atau mengalami institusionalisasi. "Society is an objective reality".

c. Internalisasi ialah individu mengidentifikasi diri di tengah lembaga- lembaga sosial atau organisasi sosial di mana individu tersebut menjadi anggotanya. "Man is a social product".

d. Menurut Heru Nugroho dalam Dekonstruksi Wacana SARA Negara dan Implikasinya Terhadap Kemajemukan Masyarakat Indonesia, gagasan konstruksi sosial telah dikoreksi oleh gagasan dekonstruksi yang melakukan interpretasi terhadap teks, wacana, yang terkenal dengan gagasan-gagasan deconstruction yang kemudian melahirkan tesis-tesis keterkaitan antara kepentingan (interest) dan metode penafsiran (interpretation) atas realitas sosial. Dalam dekonstruksi, kepentingan tertentu selalu mengarahkan kepada pemilihan metode penafsiran.

Sejalan dengan hal tersebut, Habermas (1972) dalam Heru Nugroho, mengatakan bahwa terdapat hubungan strategis antara pengetahuan manusia (baik empirik-analitik, historis hermeneutik, maupun kritis) dengan kepentingan (teknis,praktis, atau yang bersifat emansifatoris) walau tidak dapat disangkal bahwa yang terjadi juga bisa sebaliknya bahwa pengetahuan adalah produk kepentingan Pendekatan konstruksi sosial atas realitas Peter L Berger dan Luckmann telah direvisi dengan melihat fenomena media massa sangat substantif dalam proses eksternalisasi, subyektivasi dan internalisasi yang kemudian dikenal sebagai "konstruksi sosial media massa". Bungin (2010) dalam Apriadi Tamburaka, menjelaskan bahwa posisi "konstruksi sosial media massa" adalah mengoreksi substansi kelemahan dan melengkapinya atas "konstruksi sosial atas realitas". Menurut perspektif tersebut, tahapan dalam proses konstruksi sosial media massa itu terjadi melalui:

a. Tahap menyiapkan materi konstruksi: Ada tiga hal penting dalam tahapan ini yakni: keberpihakan media massa kepada kapitalisme, keberpihakan semu kepada masyarakat, keberpihakan kepada kepentingan umum.

b. Tahap sebaran konstruksi: prinsip dasar dari sebaran konstruksi sosial media massa adalah semua informasi harus sampai pada khalayak secara tepat berdasarkan agenda media. Apa yang dipandang penting oleh media, menjadi penting pula bagi pemirsa atau pembaca.

c. Tahap pembentukan konstruksi realitas. Pembentukan konstruksi berlangsung melalui: (1) konstruksi realitas pembenaran; (2) kedua kesediaan dikonstruksi oleh media massa; (3) sebagai pilihan konsumtif. 
d. Tahap Konfirmasi. Konfirmasi adalah tahapan ketika media massa maupun penonton memberi argumentasi dan akuntabilitas terhadap pilihannya untuk terlibat dalam pembetukan konstruksi.

Pada kenyataanya, realitas sosial itu berdiri sendiri tanpa kehadiran individu baik di dalam maupun di luar realitas tersebut. Realitas sosial memiliki makna, manakala realitas sosial dikonstruksi dan dimaknai secara subyektif oleh individu lain sehingga memantapkan realitas itu secara obyektif. Individu mengkostruksi realitas sosial, dan merekonstruksinya dalam dunia realitas, memantapkan realitas itu berdasarkan suyektivitas individu lain dalam institusi sosialnya.

\section{Kepentingan Ekonomi Politik dan Realitas yang Termediasi oleh Media}

Tarik-menarik kepentingan antara media lokal dengan elit politik dalam polemik pemilukada Aceh 2012 dimungkinkan terjadi karena beberapa penyebab yang berpangkal pada profesionalisme media. Profesionalisme media dapat dilihat dari produk akhir media berupa isi atau teks, yang secara sederhana terlihat dari berita yang disajikan tentang polemik pemilukada yang ditampilkan kurang berimbang. Selanjutnya merujuk pada dinamika sosial budaya, ekonomi politik, konteks sejarah, dan regulasi media. Dalam proses perpolitikan dan demokrasi, media massa adalah media yang mempunyai tingkat pengaruh yang cukup signifikan. Pendekatan ekonomi politik memfokuskan pada kajian utama tentang hubungan antara struktur ekonomi-politik, dinamika media, dan ideologi media itu sendiri, yang kemudian mengarah pada kepemilikan, kontrol serta kekuatan operasional pasar media. Produksi media ditentukan oleh berbagai macam kondisi tekanan ekspansi pasar dan juga ditentukan kepentingan ekonomi-politik pemilik modal dan pembuat kebijakan media. Dimana kepentingan tersebut berkaitan dengan kebutuhan untuk memperoleh keuntungan, sebagai akibat dari adanya kecenderungan monopolistis dan proses integrasi, baik secara vertikal maupun horisontal.

Dalam perspektif ekonomi politik kritis ekstensifikasi dominasi media dikontrol melalui dominasi produksi isi media yang sejalan dengan preferensi pemilik modal. Proses komodifikasi media massa memperlihatkan dominasi peran kekuatan pasar.

Base (2009) dalam Henry Subiakto dan Rachmah Ida, menulis bahwa akar dari ekonomi politik media bermula dari pandangan-pandangan dan konsepsi yang lahir dari pakar culture studies (studi budaya) seperti Theodore Adorno, Richard Hogart, Raymond William, dan E.P. Thompson yang memperkenalkan teori tentang 'cultural materialism'. Menjelaskan bahwa budaya telah menjadi komoditas yang dihasilkan dengan kepentingan tertentu pembuatnya untuk kepentingan memperoleh keuntungan finansial.

Dalam kepemilikan media massa, Peter Golding dan Graham Murdock (2000) dalam Henry Subiakto dan Rachmah Ida, berpendapat bahwa media massa adalah produsen budaya yang lebih berperan sebagai mesin bisnis pencari keuntungan. Dimana ideologi kapitalisme telah meresap dalam institusi media, serta mewarnai hubungan antara pemilik dan para pekerjanya. Walau teks dan isi dari berita oleh media tersebut tidak menampakkan dukungannya terhadap kapitalisme, tapi pada dasarnya isinya lebih mengarah untuk melayani kepentingan pasar. Perusahaan media sebagai institusi kapitalis, bisnisnya telah menjangkau kemana-mana, namun kontrol kepemilikan terpusat pada beberapa orang saja.

Melihat dari pendapat tersebut, jika kita melihat ke dalam wacana dari setiap isi pemberitaan media yang muncul, baik dalam bentuk teks, percakapan, atau apapun, tidak dilihat sebagai sesuatu yang alamiah, wajar dan objektif atau netral, tapi merupakan 
bentuk dari petarungan kekuasaan. Kekuasaan yang dimaksud adalah kontrol dari satu orang atau kelompok mengontrol orang atau kelompok lain lewat lewat wacana yang telah dikontruksi dan dibingkai. Seseorang yang memiliki kekuasaan lebih dan dominan mempunyai kekuasaan tidak hanya dalam menentukan bagian mana yang perlu ditampilkan dan man yang tidak, tetapi juga bagaimana ia harus ditampilkan. Misalnya dapat dilihat dari perulangan berita, penonjolan realitas atau pemakaian kata-kata tertentu.

Ketika bisnis media mulai diatur oleh tokoh-tokoh pemodal, para elite penguasa dan pengusaha berkolaborasi dalam mengatur isi media. Sehingga kebebasan dari pers ataupun jurnalis, telah disusupi oleh propaganda- proganda dari kepentingan segelintir orang. Setiap berita telah dikonstruksi oleh pemodal dengan kekuatan politik dan bisnis.

Chomsky (2000) menilai bahwa adanya konspirasi dari para elite dalam mengontrol mengkonstruksi realitas kedalam berita dan informasi. Ia melihat media telah menjadi alat kepentingan politik, ekonomi, militer, dan kultur kalangan penguasa. Menurutnya, para gate keeper media telah menjadi pion politisi dan pemodal untuk mencari keuntungan. Dengan kata lain, atas nama politik atau bangsa, para penguasa mengatur setiap pemberitaan sesuai dengan keinginan dan kepentingan mereka.

Realitas politik kekinian, sangat diburu oleh media. Politik selalu menjadi topik utama (trending topic) pemberitaan di mainstream media. Bahkan, menjadi perbincangan renyah masyarakat di beberapa media sosial. Hampir setiap hari, selalu ada politisi yang muncul di televisi dan radio sebagai narasumber talkshow politik, wawancara mendalam di koran dan majalah, hingga eksis secara pribadi di berbagai account sosial. Realitas yang sudah menjadi rahasia umum bahwa politisi beralih panggung ke media, dengan keberadaannya yang rajin mengikuti perkembangan politik, secara otomatis memberi peran pada politisi sebagai aktor utama dalam panggung politik media.

Beralihnya panggung politik dari kawasan keterwakilan ke ruang publik yang lebih luas yakni media, membuat para politisi sadar akan penampilan mereka. Performa yang disuguhkan tidak lagi hanya kualitas politik namun juga seni penampilan dan seni peran. Bagaimana pun media adalah panggung, sehingga setiap politisi yang tampil harus menguasai "seni pementasan". Saat politisi masuk media, mereka pun dibayar dan media juga mendapat iklan. Pada akhirnya, yang ditakutkan adalah eksistensi kini tak lagi diukur dari hasil kerjanya melainkan seberapa sering tampil di media, yang tentu hal ini merugikan sekaligus mengorbankan hak-hak politik publik.

Namun perlu disadari bahwa peran politisi di media bukan layaknya selebriti yang berperan dengan beda karakter. Mereka harus tampil maksimal ketika menunjukkan tanggung jawab politik yang sebenarnya dan bukan menyuguhkan hal-hal politik yang bersifat imajiner. Perbedaan peran yang dilakukan politisi terletak pada framing politik, membangun isu, menyusun wacana, dan pengembangan pemaknaan politik bagi publik. Hal itu menjadi modal penting bagi politisi dalam menyadari dan mendefinisikan situasi politik yang terjadi di media.

Pendapat Erving Goffman (dalam Eriyanto, 2002), tentang definisi terhadap situasi dapat dibedakan menjadi strip dan frame. Strip merupakan sebuah sekuen aktivitas, sedangkan frame merupakan pola pengaturan dasar yang digunakan untuk mendefinisikan strip. Pemahaman politisi terhadap strip politik menjadi penting agar peran demi peran tak melenceng dari rundown politik media. Saat tampil, politisi dan media sama-sama memegang peran penting dalam mengedukasi publik mengenai situasi politik yang terjadi, sehingga sekuen politik yang akan dibahas harus dikuasai. Menurut Siti Aminah dalam jurnalnya, Politik media merupakan sebuah sistem politik, istilah ini untuk membandingkan dengan sistem-sistem lainnya, seperti politik legislatif, politik birokrasi, politik yudisial, serta politik partai. Dalam setiap domain tersebut, dapat diidentifikasi peran kunci, kepentingan yang bermacam-macam, aturan perilaku 
yang rutin, serta politik interaksi yang mapan, yang bila digabungkan dapat memperjelas bentuk khusus dari perpolitikan.

Aminah menambahkan, bahwa terdapat 3 (tiga) pelaku dalam politik media, yakni; politisi, jurnalis, dan orang-orang yang digerakkan oleh kepentingan khusus. Bagi politisi, tujuan dari politik media untuk dapat menggunakan komunitas massa dalam memobilisasi dukungan publik yang mereka perlukan untuk kemenangan dalam pemilu dan memainkan program ketika duduk di ruangan kerja. Bagi jurnalis, tujuan politik media untuk membuat tulisan yang menarik perhatian khalayak dan menekankan apa yang disebut dengan "suara independen dan signifikan dari para jurnalis". Sedangkan bagi masyarakat, tujuannya untuk keperluan mengawasi politik

dan menjaga politisi agar tetap akuntabel, dengan menggunakan basis usaha yang minimal.

\section{Gramsci dan Kekuatan Hegemoni dalam Mengontrol Media}

Dalam hal awal membahas tentang hegemoni, sebenarnya sangat sulit mendefinisikannya. Ini rupanya susah untuk dijawab ketika kita membicarakan Gramsci, karena, setidaknya dalam The Prison Notebooks, ia tidak pernah memberikan definisi yang pas terhadap istilah itu. Ini mungkin alasan utama kenapa terdapat begitu banyak ketidak-konsistenan dalam literatur hegemoni, orang cenderung membentuk definisinya sendiri, berdasarkan pembacaan mereka sendiri terhadap Gramsci dan sumbersumber lainnya. Yang menjadi masalah di sini adalah bila seseorang membaca Gramsci secara setengah-setengah maka definisi mereka pun seperti itu.

Contohnya, Martin Clark mendefinisikan hegemoni sebagai "cara kelas penguasa mengontrol media dan pendidikan". Meskipun definisi ini mungkin lebih sempit dari biasanya, ia mencerminkan kesalahan-pembacaan yang biasa terjadi terhadap konsep tersebut, yakni bahwa hegemoni adalah cara kelas penguasa mengontrol institusi-institusi yang mengontrol atau mempengaruhi pemikiran kita. Walau demikian, kebanyakan literatur hegemoni di kalangan akademik dan aktivis mengambil sudut pandang yang sedikit lebih lebar dari ini, dengan menyertakan lebih banyak institusi dalam pelakasanaan hegemoni - setidaknya menyertakan juga militer dan sistem politik. Problemnya adalah bahkan ketika institusi-institusi ini diperhitungkan, fokusnya cenderung eksklusif kepada kelas penguasa, dan metode-metode kontrolnya. Hegemoni sering kali digunakan untuk menggambarkan cara kelas-kelas kapitalis menginfiltrasi pikiran rakyat dan menerapkan dominasinya. Yang luput dari definisi ini adalah Gramsci tidak hanya menggunakan istilah "hegemoni" untuk menggambarkan aktivitas kelas penguasa, ia juga menggunakannya untuk mendeskripsikan pengaruh yang diberikan oleh kekuatankekuatan progresif. Dengan mencamkan hal ini, kita dapat melihat bahwa hegemoni seharusnya didefinisikan sebagai hal yang dilakukan bukan saja oleh kelas penguasa, faktanya ia adalah proses di mana kelompok-kelompok sosial (apakah mereka progresif, regresif, reformis, dan lain sebagainya) meraih kekuasaan untuk memimpin, bagaimana mereka memperluas kekuasaan mereka dan mempertahankannya.

Untuk memahami apa yang coba dicapai oleh Gramsci ketika mengembangkan teori hegemoninya, kita butuh melihat konteks historis yang ia hadapi maupun perdebatan dalam pergerakan di masa itu. Istilah "hegemoni" sudah umum digunakan oleh lingkaran sosialis sejak awal abad 20. Penggunaannya menunjukkan bahwa bila suatu kelompok digambarkan sebagai "hegemonik" maka ia menempati posisi kepemimpinan dalam suatu ranah politik tertentu. Penggunaan istilah gegemoniya (istilah Rusia untuk hegemoni, sering diterjemahkan sebagai vanguard) oleh Lenin tampak menyiratkan suatu proses yang lebih mirip dengan apa yang digambarkan oleh Gramsci. Dalam upayanya mengkatalisis Revolusi Rusia, Lenin melakukan pengamatan bahwa ketika dibiarkan 
mengurus sendiri, kaum pekerja cenderung hanya mencapai kesadaran serikat buruh, memperjuangkan keadaan yang lebih baik dalam sistem yang ada. Untuk menghadirkan perubahan revolusioner, ia berargumen bahwa kaum Bolshevik perlu menempati posisi hegemonik dalam perjuangan menentang rejim tsaris. Ini artinya bukan saja memberdayakan berbagai serikat pekerja dengan menyatukan mereka, tapi juga melibatkan semua "strata oposisi" dalam masyarakat ke dalam gerakan, menarik hubungan-hubungan di antara semua bentuk "penindasan politik dan kesewenangwenangan otokratik".

Namun, dalam periode paska revolusioner implikasinya berubah. Lenin berargumen bahwa hal-hal krusial untuk mendirikan "hegemoni proletariat". hegemoni proletariat adalah pertama, kaum proletariat perkotaan mempertahankan aliansinya dengan kaum tani pedesaan (yang merupakan mayoritas penduduk Rusia) untuk mempertahankan kepemimpinan nasional dan kedua adalah keahlian kaum kapitalis lama digunakan, dengan memaksa mereka untuk secara efektif mengelola industri-industri negara. Kedua proses kepemimpinan ini yang dilakukan via konsensus dan penggunaan paksaan dalam pengembangan hegemoni akan memainkan peran yang krusial dalam teori Gramsci. Dari tahun 1922-1923 Gramsci berada di Rusia ketika perdebatan-perdebatan ini sedang menggelora dan setelah masa-masa inilah kita melihat hegemoni mulai menempati peran sentral dalam tulisan- tulisannya.

Di samping pengaruh yang diakibatkan oleh jalannya peristiwa di Rusia, Gramsci juga dipengaruhi oleh pengalaman politiknya sendiri. Gramsci sangat terlibat dalam perjuangan melawan kapitalisme dan fasisme di Italia dan untuk beberapa waktu ia merupakan pemimpin Partai Komunis Italia. Dalam periode setelah Perang Dunia I, terdapat optimisme yang besar di Eropa, dan khususnya di Italia, karena saat itu rakyat melihat penindasan yang dilakukan oleh kelas-kelas penguasa, sementara di Rusia suatu alternatif sedang berkembang, sehingga semacam revolusi kaum pekerja di Eropa pun mulai tampak di permukaan.

Gramsci tentunya meyakini optimisme ini. Peristiwa yang berlangsung di awal 1920an tampak mengonfirmasikan ini. Ketegangan dalam semua strata masyarakat adalah tinggi, terdapat agitasi massa dan rakyat membentuk dewan-dewan pabrik dan koperasi pekerja. Tapi terlepas dari mobilisasi yang intens ini, itu semua padam dengan segera. Serikat-serikat buruh terkooptasi, koperasi pekerja menjadi tersingkir dan tak kompetitif. Rakyat biasa diintimidasi oleh elit atau terpesona oleh daya tarik retorika fasis.

Sebagaimana dijelaskan di atas, dalam The Prison Notebooks Gramsci mengacu pada hegemoni untuk menggambarkan aktivitas kelompok yang sedang dominan maupun kekuatan-kekuatan progresif. Bagi Gramsci, apa pun kelompok sosialnya, kita dapat melihat bahwa terdapat tahapan perkembangan bersama tertentu yang harus mereka lalui sebelum mereka dapat menjadi hegemonik. Mengambil dari Marx, persyaratan pertama adalah ekonomi: bahwa kekuatan material telah cukup dikembangkan sehingga orang-orang di dalamnya mampu memecahkan problem-problem sosial yang paling mendesak. Gramsci kemudian berlanjut menyatakan bahwa terdapat tiga tingkat perkembangan politik yang harus dilalui suatu kelompok sosial agar dapat mengembangkan gerakan yang dapat memulai perubahan.

Tahap pertama dari ini disebut "korporat-ekonomis". Seorang korporatis mungkin adalah apa yang kita pahami sebagai individu yang mengutamakan kepentingannya sendiri. Seseorang berafiliasi dengan tahap korporat-ekonomis sebagai fungsi dari kepentingan pribadinya, menyadari bahwa mereka membutuhkan dukungan orang lain untuk memperoleh keamanan mereka sendiri. Serikat-buruhisme mungkin merupakan contoh terjelas untuk ini, setidaknya dalam kasus di mana orang bergabung dengan serikat buruh karena takut gajinya dipotong, dan penyusutan. Dalam istilah ini, 
kita juga dapat memasukkan kerjasama jangka-pendek antara kapitalis- kapitalis yang sesungguhnya saling berkompetisi satu sama lainnya. Hal yang ditekankan adalah: pada tahap perkembangan historik ini, kelompok yang bersangkutan belum memiliki rasa solidaritas di antara anggota-anggotanya.

Dalam tahap kedua, anggota-anggota kelompok mulai menyadari bahwa terdapat wilayah kepentingan yang lebih luas dan bahwa terdapat orang lain yang berbagi kepentingan dengan mereka dan akan terus membagi kepentingan-kepentingan ini dalam masa depan yang terjangkau. Dalam tahap inilah rasa solidaritas berkembang, tapi solidaritas ini masihlah hanya berbasiskan kepentingan ekonomi bersama. Tidak terdapat pandangan dunia bersama atau apa pun semacam itu. Solidaritas seperti ini dapat mengarah pada upaya-upaya untuk menggalakkan reformasi-reformasi di bidang hukum untuk memperbaiki posisi kelompok tersebut dalam sistem yang ada, tapi belum ada kesadaran tentang bagaimana mereka, dan yang lainnya, dapat diuntungkan oleh pembentukan sistem yang baru.

Hanya dengan melewati tahap ketiga maka hegemoni dapat benar-benar menjadi mungkin. Dalam tahap ini, anggota-anggota kelompok sosial mulai menyadari kepentingan dan kebutuhan untuk menjangkau melampaui apa yang dapat mereka lakukan dalam konteks kelas-kelas mereka tersendiri. Yang dibutuhkan adalah agar kepentingan mereka turut diusung oleh kelompok-kelompok lainnya yang tersubordinasi seperti halnya mereka. Inilah yang dipikirkan oleh Lenin dan kaum Bolshevik dalam membentuk aliansi dengan kaum tani - bahwa hanya dengan membuat revolusi Bolshevik juga menjadi revolusi kaum tani, di mana kaum tani juga melihat itu sebagi revolusi mereka, maka kaum proletariat perkotaan dapat mempertahankan posisi kepemimpinannya.

Gramsci memahami bahwa dalam konteks historis yang sedang dikerjakannya, berjalannya suatu kelompok sosial dari reformisme atas kepentingan pribadi menuju hegemoni nasional dapat terjadi secara efektif via partai politik. Dalam formulasi yang kompleks ini, beragam ideologi kelompok-kelompok yang beraliansi akan berkumpul. Tak dielakkan lagiakan terjadi konflik antara ideologi-ideologi ini, dan melalui proses perdebatan dan pertarungan, satu ideologi, atau kombinasi penyatuan darinya, akan muncul mewakili kelas-kelas yang beraliansi. Ideologi ini dapat dibilang hegemonik, kelompok yang mewakilinya telah meraih posisi hegemonik atas kelompok-kelompok yang tersubordinasi. Dalam tahap ini, partai mencapai kedewasaan dengan meraih kesatuan antara tujuan ekonomi dan politik maupun kesatuan moral dan intelektual - dapat dikatakan sebagai saling berbagi suatu pandangan dunia.

Dengan persatuan ini di belakangnya, partai mentransformasi masyarakat untuk meletakkan persyaratan bagi ekspansi kelompok hegemonik. Negara menjadi mekanisme untuk melakukan ini: kebijakan dihasilkan dan ditegakkan untuk memungkinkan kelompok hegemonik mencapai tujuan-tujuannya secara efektif dan menciptakan simetri antara tujuannya dan tujuan kelompok-kelompok lainnya. Meskipun tujuan-tujuan ini diformulasikan dengan pemikiran untuk memajukan kepentingan satu kelompok, walau demikian tujuan-tujuan tersebut harus dialami oleh penduduk sebagai kepentingan semua orang. Agar ini berjalan efektif, kelompok hegemonik harus memiliki suatu bentuk tertentu dalam menangani kepentingan kelas-kelas yang tersubordinasi. Kepentingan yang dominan tidak dapat dengan begitu saja diterapkan kepada mereka.

Meskipun Gramsci menganggap langkah-langkah pragmatis tersebut dibutuhkan oleh tiap kelompok yang hendak meraih kekuasaan, ia juga memiliki kepedulian etis yang sangat mendalam terhadap cara berjalannya proses tersebut. Dalam pengertian ini, kita dapat menemukan dalam karya Gramsci perbedaan kualitatif antara pelaksanaan hegemoni 
oleh kelompok regresif dan otoriter di satu pihak, dan kelompok-kelompok sosial di pihak lainnya. Dalam tingkat etika, Gramsci di atas segalanya ialah seorang anti-dogmatis yang meyakini bahwa kebenaran tak dapat diterapkan begitu saja dari atas-ke-bawah, tapi hanya melalui dialog yang konkrit dan simpatik dengan rakyat. Kalau hegemoni regresif melibatkan penerapan serangkaian nilai-nilai yang tak ternegosiasikan kepada rakyat, terutama melalui paksaan (koersi) dan penipuan, hegemoni progresif akan berkembang dengan persetujuan (konsen) masyarakat yang diraih secara demokratis.

Jelaslah bila kita menelusuri sejarah, kelas kapitalis memegang hegemoninya terutama melalui berbagai bentuk paksaan (koersi), yang berkisar dari penempatan militer secara langsung hingga bentuk-bentuk yang lebih halus, contohnya, menggunakan kekuatan ekonomi untuk menyingkirkan lawan politik. Namun, adalah suatu kesalahan besar untuk berpikir bahwa kapitalisme tidak pula bergantung pada pembangunan persetujuan atau konsensus. Bahkan dapat diargumentasikan bahwa pembangunankonsensus kapitalismelah yang dari sudut pandang strategis perlu kita beri perhatian lebih mendalam, karena di tingkat inilah kita berkompetisi dengan mereka. Sifat dan kekuatan konsensus ini beragam. Ada cara-cara di mana kapitalisme sukses secara aktif menjual visinya kepada kelas-kelas yang tersubordinasi. Ini bukan berarti sekedar menjual visi terdistorsi tentang suatu masyarakat yang bebas, merdeka, inovatif, tapi juga menggunakan ide-ide ekonomi borjuis untuk meyakinkan kelas pekerja untuk meyakini bahwa, contohnya, meskipun kebijakan kapitalis adalah kepentingan utama kelas kapitalis, mereka pun akan meraih keuntungan via dampak tetesan-ke-bawah (trickle down effects). Kapitalisme juga dapat memenangkan persetujuan atau konsensus di antara mereka yang mungkin tidak mempercayai bahwa sistem yang ada adalah untuk kepentingan mereka, namun meyakini bahwa tidak ada alternatif atau bahwa alternatif akan lebih buruk - dengan kata lain, dengan menggalakan keyakinan bahwa sistem yang ada merupakan suatu keharusan yang dibutuhkan (necessary evil).

Abad ke-20 menyaksikan kapitalisme memperluas secara massif bentuk konsensus ini, terutama melalui kontrol korporasi dalam media dan periklanan. Di Amerika Serikat khususnya, penggalakkan American dream, dan semua komoditas tak bermanfaat yang dibutuhkan untuk meraihnya, tidak hanya berguna untuk menggenjot konsumsi dan sekaligus menguntungkan kepentingan ekonomi kaum kapitalis; ia juga menjual suatu gaya hidup yang hanya dapat diberikan oleh kapitalisme. Ini tentunya dibantu selama Perang Dingin dengan berbagai upaya simultan untuk mencap tiap alternatif terhadap kapitalisme sebagai perbudakan. Kelas kapitalis menentang tiap kebijakan yang berupaya menyaingi media milik korporasi dengan menggunakan kekuatan politik hegemoniknya untuk menciptakan kondisi-kondisi bagi pembangunan konsensus lebih jauh, yang kemudian akan memperluas kepentingan mereka. Kelompok hegemonik akan terus berjuang dengan cara-cara ini untuk mencapai tingkat konsensus yang lebih besar - dalam kasus ini dengan mengunci rakyat ke dalam cara berpikir yang kaku dan menggilas tiap optimisme.

Beberapa bentuk serikat-buruhisme tertentu dapat juga menjadi contoh hegemoni kapitalis. Apa yang Gramsci sebut sebagai "sindikalisme" (pandangan bahwa kondisi kelas pekerja dapat diangkat secara maksimal dengan meningkatkan kekuatan serikat buruh) mencerminkan suatu kelompok sosial (para pekerja) yang terperosok dalam tahap perkembangan korporat-ekonomis akibat pengaruh hegemonik kapitalis, terutama para pembela perdagangan bebas (free trade), dalam ranah ideologi. Para pembela perdagangan bebas berargumen bahwa negara dan masyarakat sipil harus tetap terpisah, bahwa negara harus keluar dari ranah ekonomi, yang berfungsi secara otonom - serahkan itu kepada "tangan pasar yang tak kasat mata" dan seterusnya. 
Kaum sindikalis mengadopsi asumsi tentang pemisahan antara ranah sosial dan ekonomi di satu sisi dan ranah politik di sisi lainnya, dan mengasumsikan bahwa mereka dapat membawa perubahan radikal tanpa perwakilan politik. Hasil konkrit dari ini adalah mereka hanya dapat bernegosiasi untuk perbaikan-perbaikan yang berpengertian sempit dalam ranah ekonomi, tanpa perubahan kebijakan yang memungkinkan kemenangankemenangan ini meraih basis yang lebih permanen. Sementara para pembela perdagangan bebas justru secara aktif terlibat dalam penentuan kebijakan (meskipun klaim mereka mengatakan lain) yang menciptakan kondisi-kondisi yang menguntungkan kelas kapitalis.

Namun, ketika kepentingan kelas kapitalis secara langsung terancam, kekuatan hegemonik tak pelak lagi beralih ke paksaan. Tidak ada lagi ruang untuk menegosiasikan ini, dalam tatanan hegemonik yang ada. Dalam tingkat sederhana, ini dapat berarti membuat legislasi yang memungkinkan polisi menyerang pekerja yang melaksanakan aksi-aksi industrial, yang mengancam profit secara langsung tapi ancaman terbesar terhadap kapitalis adalah perkembangan alternatif hegemonik dalam masyarakat sipil. Ancamannya adalah rakyat akan beralih dari fase korporat-ekonomis, dan menyadari bahwa kepentingan mereka bersinggungan dengan semua pihak yang dipinggirkan oleh kapitalisme dan melawan balik, bahwa mereka akan menyadari kekuatan mereka dan menuntut perubahan radikal karena ini merupakan ancaman terbesar terhadap kapital, cara paling efektif baginya untuk menggunakan paksaan adalah dengan memecah belah aliansi-aliansi progresif antara kelompok-kelompok yang tersubordinasi. Ketika dihadapkan pada kekerasan dan ancaman-ancaman ekonomi, orang lebih tidak mampu menghubungkan dirinya dengan kelompok. Kekuatiran untuk bertahan hidup berarti bahwa tiap orang harus mempertahankan kepentingan mereka secara individual. Hegemoni progresif dari pergerakan menjadi terhambat, karena tiap orang dipaksa untuk bertindak secara korporatis. Kelas penguasa juga dapat berupaya memecah belah gerakan secara kasar dengan memanas- manasi perbedaan ideologi, contohnya dengan berseru tentang agama.

Gramsci memandang bahwa perkembangan hegemoni progresif melibatkan lebih banyak keterbukaan, demokrasi dan konsensus, dibandingkan paksaan. Kalau pun terdapat paksaan, itu seharusnya ada untuk melawan kekuatan-kekuatan reaksioner yang hendak menjegal perkembangan masyarakat. Ini akan memberikan ruang kepada massa untuk meraih potensi mereka. Bagian yang besar dari The Prison Notebooks diberikan untuk mencari tahu apa yang dibutuhkan untuk mengembangkan hegemoni semacam ini, dan banyak pemikir Gramscian sejak itu mendedikasikan diri mereka untuk menjawab teka-teki ini.

Sebagai awalan, kita dapat mengatakan bahwa hegemoni yang ada mencoba menjaga agar kelompok-kelompok yang dikecewakan dan tersubordinasi tetap tercerai berai, hegemoni progresif yang hendak bangkit harusnya mempersatukan mereka. Gramsci tentunya melihat tantangan yang ada di sini. Dalam situasi historisnya sendiri (dan tak diragukan lagi masih demikian pada masa kita kini) terdapat rintangan-rintangan yang cukup besar antara kelompok-kelompok yang terpinggirkan dalam hal pengalaman, bahasa dan pandangan-dunia. Namun, yang sama-sama dimiliki oleh semua kelompok ini adalah tidak ada dari mereka yang memiliki perwakilan politik yang memadai dalam sistem yang ada. Gramsci menyebut kelompok- kelompok yang tak memiliki perwakilan politik ini "subalternus". Tantangan kelompok hegenomik adalah memberikan kritik terhadap sistem yang ada dengan sedemikian rupa sehingga kelompok-kelompok subalternus tersebut menyadari kesamaan nasib mereka dan kemudian "bangkit" ke dalam kehidupan politik partai. Untuk memfasilitasi penggabungan oleh pihak-pihak lainnya ini, Gramsci menekankan perlunya kelompok hegemonik untuk bergerak melampaui pemahaman kepentingannya sendiri yang korporatis- ekonomis, mengorbankan beberapa 
tujuan ekonomi yang mendesak demi kesatuan moral dan intelektual yang lebih mendalam. Ia harus meninggalkan prasangka-prasangka dan dogma-dogma tradisionalnya dan mengambil pandangan yang lebih luas bila hendak memimpin sambil mendapat kepercayaan dan konsensus (keduanya dibutuhkan untuk mengalahkan kekuasaan yang ada).

Bila kekuatan yang segaris ini hendak memiliki pengaruh historis yang penting, mereka harus langgeng dan secara organik/menyatu berhubungan dengan kondisikondisi di lapangan, bukan sekedar konvergensi sesaat. Untuk mengembangkan momentum massa, mereka harus mendemonstrasikan, baik dalam imajinasi rakyat maupun dalam aksi, bahwa mereka mampu meraih kekuasaan dan melaksanakan tugas-tugas yang mereka tetapkan sendiri. Tugas-tugas ini harus secara efektif menjadi tugas setiap orang - mereka harus mewakili tiap aspirasi, dan menjadi pemenuhan dari tugas gerakan- gerakan yang tidak berhasil dalam generasi sebelumnya.

Berdasarkan pada teori hegemoni Gramsci, kekuasaan bagian dari proses hegemoni itu. Maka, kekuasaan diartikan sebagai kondisi kemampuan seseorang atau kelompok bertujuan untuk mempengaruhi tingkah laku orang lain atau kelompok sesuai dengan keinginan penguasa dan untuk mencapai kekuasaan itu dibutuhkan strategi-strategi mempertahankan dan melestarikan kekuasaan. Bahkan, dengan menautkan kekerasan melalui militerisme.

Media pada dasarnya mempunyai fungsi dan peran untuk menyampaikan informasi kepada masyarakat. Posisinya begitu strategis di masyarakat. Bahkan, media mampu membentuk struktur dan tatanan sosial baru masyarakat. Salah satunya media lokal yang dapat mengakomodir kebutuhan-kebutuhan masyarakat yang besar dan kompleks di satu sisi, tapi sekaligus anomi.

Bagi penguasa, media merupakan alat yang paling sesuai untuk menggiring masyarakat kepada kepatuhan dan kepentingan penguasa. Media bisa saja dijadikan sebagai alat propraganda. Sehingga, tidak heran kerja sama kepentingan politik sering terjadi antara elite politik dengan organisasi kepemilikan media massa. Kolaborasi itu untuk membangun struktur masyarakat sebagaimana yang mereka inginkan dalam rangka melanggengkan kekuasaan. Melihat kondisi seperti itu, Gramsci menilai media massa merupakan perangkat hegemoni dari penguasa. Di negara demokratis, media massa turut serta dalam penentuan kebijakan kekuasaan politik. Pada pemilukada di Aceh, misalnya, telah terjadi kolaborasi antara penyelenggara kekuasaan politik dengan salah satu media lokal. Selain itu, media massa bahkan menjadi pendukung suatu partai atau kandidat pemegang kekuasaan politik. Pesan yang disajikan cenderung menumbuhkan citra positif dari program partai atau kandidat. Dengan demikian sulit melihat posisi kenetralan media. Ia tidak lepas dari kepentingan penguasa atau pun pengusaha. Media, dengan teks, gambar, dan berbagai simbol lain kemudian menjadi teror yang menyusup di balik kesadaran manusia. Ia bisa menjadi sebentuk teror yang baik, mencerahkan, dan mencerdaskan. Sebaliknya, media massa juga bisa menjadi mimpi buruk. Menjadi teror kesadaran, lalu menggiring kesadaran kita pada apa yang dikehendaki media.

Terlepas dari pro dan kontra, teori kultivasi mengemukakan bahwa realitas pada media dianggap sebagai realitas yang sesungguhnya. Dimana kejadian yang disajikan oleh media media dianggap sebagai representasi keadaan sesungguhnya di masyarakat. Terlihat pada pemilukada Aceh 2012, media lokal Aceh (Serambi Indonesia dan Modus Aceh) memberitakan kondisi pemilukada Aceh yang tidak kondusif berpolemik. Padahal, berita itu bertolak belakang dengan kondisi sesungguhnya. Media seolah membuat hiper realitas, membesar-besarkan realitas dengan menaikan skala isunya. Dengan 
demikian, siapa yang mengendalikan pesan media massa dapat pula mengendalikan opini publik. Siapa yang mengendalikan opini publik dia pun akan memiliki kekuasaan.

\section{DAFTAR PUSTAKA}

Abar, Akhmad Zaini, Kisah Pers Indonesia, 1966-1974, (Yogyakarta: LKiS, 1995). Alridge, Meryl, Understanding the Local Media, (Berkshire \& New York: McGraw-Hill \& Open University Press, 2007).

Anderson, Benedict R. O'G., Imagined Communities: Reflections on the Origin and Spread of Nationalism, (London: Verso, 1983).

Aspinall, Edward, "Kemenangan Modal? Politik Kelas dan Demokratisasi Indonesia", Prisma, 32, 1 (2013).

Blumler, Jay G., Jack M. McLeod, Karl Erik Rosengren (eds.), Comparatively Speaking: Communication and Culture Across Space and Time, (California: Sage Publications, 1992).

Brauchler, Birgit, "The Transformation of Media Scene: From War to Peace in the Moluccas, Eastern Indonesia", Kishna Sen \& David T. Hill (eds.), Politics and the Media in Twenty-First Century Indonesia: Decade of Democracy, (London \& New York: Routledge, 2011): 119- 40.

Burhanuddin \& Jamaluddin, "Out of Frame: Studi Pemberitaan Pemilukada Provinsi Jambi 2010 oleh Media Lokal di Jambi”, laporan penelitian, (2010).

Dhakidae, Daniel, "The State, the Rise of Capital and the Fall of Political Journalism: Political Economy of Indonesian News Industry", disertasi di Cornell University, (1991).

Durham \& Douglas M. Kellner (eds.), Media and Cultural Studies: KeyWorks, (USA: Blackwell, 2006).

Eriyanto, "Koran, Bisnis, dan Perang", Andreas Harsono \& Budi Setiyono (eds.), Jurnalisme Sastrawi: Antologi Liputan Mendalam dan Memikat, (2008): 203-232.

Eriyanto, Media dan Konflik Ambon: Media, Berita, dan Kerusuhan Komunal di Ambon, 1999- 2002, (Jakarta: Kantor Berita Radio 68H, 2003).

Franklin, Bob, "Local Journalism and Local Media: Contested Perceptions, Rocket Science and Parallel Universes", Bob Franklin (ed.), Local Journalism and Local Media: Making the Local News, (London \& New York: Routledge, 2006).

Hadiz, Vedi R., "Komoditas, Modal, dan Wajah Ekonomi-Politik Bangsa”, Prisma, 32, 1, (2013).

Hadiz, Vedi R., "Studies in the Political Economy of New Order Indonesia", Kyoto Review of Southeast Asia, 1 (2002). 
Hallin, Daniel C. \& Paolo Mancini, Comparing Media System: Three Models of Media and Politics, (Cambridge \& New York: Cambridge University Press, 2004).

Haryanto, Ignatius, "Menilik Pers Lokal 10 Tahun Setelah Reformasi", Jurnal Dewan Pers, 5 (2011).

Hill, David T. \& Krishna Sen, The Internet in Indonesia's New Democracy, (London \& New York: Routledge, 2007).

Hill, David T., "Media and Politics in Regional Indonesia: The Case of Manado", Krishna Sen \& Terence Lee (eds.), Political Regimes and the Media in Asia, (London \& New York: Routledge, 2008): 188-207.

Hill, David T., "On the Border: Local Media in the Land of Papua", Kishna Sen \& David T. Hill (eds.), Politics and the Media in Twenty-First Century Indonesia: Decade of Democracy, (London \& New York: Routledge, 2011$)$ : $26-48$.

Ida, Rachmah, "Reorganisation of Media Power in Post-Authoritarian Indonesia: Ownership, Power and Influence of Local Media Entrepeneurs", Krishna Sen \& David T. Hill (eds.), Politics and the Media in Twenty-First Century Indonesia: Decade of Democracy, (London \& New York: Routledge, 2011): 13-25.

Kuntowijoyo, Penjelasan Sejarah, (Yogyakarta: Tiara Wacana, 2008).

Lim, Merlyna, @Crossroads: Democratization and Corporatization of Media in Indonesia, (Arizona: Participatory Media Lab \& Ford Foundation, 2011).

Lim, Merlyna, The League of Thirteen: Media Concentration in Indonesia, (Arizona: Participatory Media Lab \& Ford Foundation, 2012).

McLuhan, Marshall, War and Peace in the Global Village, (New York: Bantam, 1968).

Mosco, Vincent, The Political Economy of Communication, 2nd edition, (London, California, New Delhi, \& Singapore: Sage, 2009).

Nordholt, Henk Schulte \& Gerry van Klinken (eds.), Renegotiating Boundaries: Local Politics in Post-Soeharto Indonesia, (Leiden: KITLV, 2007

Obet, "Relasi Kapitalisme dengan Organisasi Media", www.koranpembebasan.wordpress.com- /2013/11/13/relasi-kapitalisme- denganorganisasi-media/, diunduh pada 12 Desember 2014.

Picard, Robert G., The Press and the Decline of Democracy: The Democratic Socialist Response in Public Policy, (Connecticut: Greenwood Press, 1985).

Piper, Tessa, Keeping Local Government Honest: Local Media's Role in Ensuring Government Accountability, (Jakarta: UNDP Indonesia, 2009). 
Robison, Richard \& Vedi R. Hadiz, Reorganising Power in Indonesia: The Politics of Oligarchy in an Age of Markets, (London \& New York: RoutledgeCurzon, 2004).

Robison, Richard, Indonesia: The Rise of Capital, (Jakarta: Equinox, 2008 [edisi perdana terbit 1986]).

Rogers, Everett M., A History of Communication Study: A Biographical Approach, (New York: Free Press, 1994).

Siebert, Peterson, and Schramm, Four Theories of the Press: The Authoritarian, Libertarian, Social Responsibility, and Soviet Communist Concepts of What the Press Should Be and Do, (Urbana: University of Illinois Press, 1963).

Simpson, Christopher, Science of Coercion: Communication Research and Psycological Warfare 1945-1960, (Oxford: Oxford University Press, 1994).

Siregar, Ashadi, "Perkembangan Media Cetak Lokal", makalah disampaikan dalam seminar Being local in National Context: Understanding Local Media and Its Struggle, Surabaya, 14 Oktober 2002.

Sreberny, Annabelle, "The Global and the Local in International Communications", M.G.

Sutrisno, Petrus Suryadi, "Fenomena Kebangkitan Industri Pers Daerah/Media Lokal", Jurnal Dewan Pers, 5 (2011): 77-90. 